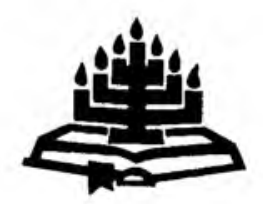

\title{
Van die Redaksie
}

Hierdie nommer van In die Skriflig word aan 'n gewaardeerde medewerker en kollega opgedra uit erkentlikheid en dankbaarheid vir sy bydrae tot die uitbou van die Gereformeerde teologie.

Wanneer sy geskrifte nagegaan word, is dit duidelik dat Christi Coetzee hom veral op die Johannese geskrifte en die leer oor die Heilige Gees toegespits het Ek herinner my goed dat hy by geleentheid opgemerk het dat die een groot leemte in die (goeie) boek van Herman Ridderbos oor Paulus die onderbeligting is wat die persoon en werk van die Heilige Gees daarin ontvang.

Sy ontydige uittrede vanweë verswakkende gesondheid het 'n leemte gelaat. Sy teologiese navorsing bly egter van blywende waarde.

Ons bid hom en Susan die krag van die Here en die leiding van sy Gees toe op hulle lewensweg vorentoe.

Amie van Wyk 